\section{Measurement of skeletal muscle tissue oxygenation in the critically ill}

\author{
IGOR STRAHOVNIK • MATEJ PODBREGAR
}

IGOR STRAHOVNIK・ MATEJ PODBREGAR $(\square)$ Centre for Intensive Care Medicine, University Clinical Centre Ljubljana, Zaloška 2, 1000 Ljubljana, Slovenia Phone: +386 15225292

Fax: + 38615222236

E-mail: matej.podbregar@guest.arnes.si

\begin{abstract}
Shock is a state of acutely reduced tissue oxygenation. In cardiogenic shock oxygen delivery (DO2) is reduced, but oxygen extraction is preserved. In septic shock DO2 is preserved, but oxygen extraction is decreased because of microvascular changes and disturbed metabolism. Global assessment of DO2 and oxygen consumption does not tell us enough about adequacy of regional perfusion. The aim of this study was to assess the value of near infrared spectroscopy (NIRS) in detecting skeletal muscle tissue oxygenation (StO2) in critically ill patients.

Patients in cardiogenic shock $(n=17)$, septic shock $(n=14)$, without shock but with localized infection $(n=14)$ and healthy volunteers $(n=15)$ were included. Thenar StO2 was measured with NIRS before (baseline StO2, \%), between (downward StO2 slope, \%/min) and after 90 seconds of upper arm stagnant ischemia (hyperemic StO2, \%). Muscle oxygen extraction (mOER) was calculated as follows: $\operatorname{mOER}(\%)=(1$-baselineStO2/hyperemic StO2)*100. Repeatability was assessed using the Bland Altman method (95\% of values within limits of agreement), comparing 55 pairs of measurements performed in 5-minute intervals.

Repeatability of measurements was clinically acceptable. Compared to septic shock patients, cardiogenic shock patients had lower baseline StO2 (68.9 $\pm 10.0 \%$ vs. $84.3 \pm 10.4 \% ; p<0.05)$ and hyperemic StO2 (80.8 $\pm 7.8 \%$ vs. $91.8 \pm 8.3 \%$; $p<0.05)$, and a higher downward StO2 slope (-17.4 $\pm 31.7 \% / \mathrm{min}$ vs. $-9.1 \pm 2.6 \% / \mathrm{min} ; p<0.05)$. mOER was higher in healthy volunteers $(11.9 \pm 3.8 \%)$ and volunteers with cardiogenic shock $(14.8 \pm 7.3 \%)$ compared to septic shock patients $(8.1 \pm 7.8 \%)$ and those with localized infection (7.6 $\pm 5.4 \%)(p<0.05)$.

Repeatability of baseline StO2 and hyperemic StO2 is clinically acceptable. Results support the hypothesis that skeletal muscle oxygen extraction capability is preserved and extraction is increased in cardiogenic shock compared to septic shock.
\end{abstract}

Key words: repeatability, NIRS, tissue oxygenation, cardiogenic shock

\section{Introduction}

Tissue hypoxia in shock correlates with a higher mortality in the critically ill. (1) Assessment of global oxygen delivery $\left(\mathrm{DO}_{2}\right)$ and consumption $\left(\mathrm{VO}_{2}\right)$ can be made with right heart catheterization using Fick's principle, based on cardiac output, hemoglobin saturation and total value of arterial and central venous blood oxygen contents. Delivery of blood through the capillaries and cellular capability to uptake and utilize oxygen define hemoglobin saturation. Where these two are intact, we see an increase in $\mathrm{VO}_{2}$ to compensate for lower blood flow. Examples are cardiogenic, hypovolemic and obstructive shock. In these states, oxygen consumption is limited only by delivery of oxygen, the relationship being linear when delivery drops below consumption capability. A different set of dynamics is seen in distributive shock, where oxygen delivery is usually maintained or even increased, while oxygen consumption is disturbed because of microvascular and metabolic changes. (2) It is not entirely clear whether microvascular shunts or mitochondrial shutdown is predominant but both are probably important. $(3,4)$
Unfortunately, measurements of global oxygen delivery and consumption, as well as of other global hemodynamic parameters, are uninformative of local tissue blood flow since it can be inadequate despite normal global parameters. (5) Additionally, these measurements are invasive which limits their usefulness since inadequate perfusion should be recognized early in shock development. (6) A good method for tissue perfusion assessment should, therefore, have to be local and noninvasive so it could be used early. In circulatory failure, blood flow redistributes from less important peripheral organs (skin, muscles, 
bowels) to vital organs (brains, heart, kidney), hence peripheral tissues can be used for early assessment of tissue perfusion.

We use various methods in clinical practice with the most important still being clinical examination of a patient's finger skin temperature, color, sweating and capillary refill. It is difficult to interpret these signs in the setting of distributive shock, with evidence that tissue hypoperfusion exists, despite normal clinical signs. $(7,8,9)$ Another method is measurement of the difference between core and peripheral temperatures. This method has poor value in the setting of low room temperature and in distributive shock. (10)

\section{Near infrared spectroscopy}

Near infrared spectroscopy (NIRS) is measuring tissue oxygenation in muscles $\left(\mathrm{StO}_{2}\right)$. $(11,12) \mathrm{NIRS}$ is a noninvasive, continuous, bedside method used for tissue oxygenation monitoring. A probe with a near infrared light source is placed on the skin where it transilluminates tissues and detects reflected light. Near infrared light (wave length 700-1000 nm) penetrates into tissue relatively well. The amount of light reflected back to the probe depends on oxygen saturation of chromophores (hemoglobin, myoglobin, cytochorme c oxidase), since saturation defines their absorption spectra. This can be seen with blood where bright red denotes arterial blood and dark blue venous blood. For now, precise quantitative analysis of hemoglobin concentration is not possible for we can only obtain relative relationships of oxygenated and deoxygenated forms of substances. This is done with the Beer-Lambert method, modified for longer paths of rays in tissues. The path of rays depends on the type of tissue, wavelength of light used and intraoptode distance (distance between emitter and detector of light) and is basically telling us the volume of tissue that is being measured. NIRS is indiscriminate towards blood vessel compartments and gives out average values of tissue saturation. Estimations suggest that relationships between arterial, venous and capillary systems are $10: 20: 70 \%$. (13) Besides continuous measurements of hemoglobin and myoglobin saturation, technology for measuring the absorption of oxydated cytochrome c only, is being developed which could be used for monitoring cellular breathing. (14)

To assess tissue consumption of oxygen in the muscles of the arm with NIRS, an area of stagnant ischemia is produced by constricting the arm with an inflatable cuff (to $260 \mathrm{mmHg}$ ), thus restricting blood flow to the hand. NIRS was used before, during and after inducing ischemia in healthy individuals. (15) During ischemia, an almost linear drop in tissue hemoglobin and myoglobin saturation was observed until it reached a plateau after 3 to 4 minutes, with no further changes. After deflating the cuff, a rapid increase in saturation was observed, reaching values higher than in the initial steady state, which returned to the initial values after around 5 minutes. The drop in saturation during ischemia has been attributed to consumption of oxygen by cells for metabolism with the plateau explained as a shut down of oxygen metabolism rather than complete desaturation of hemoglobin. Increase in saturation after ischemia results from reperfusion and reactive hyperemia. In healthy individuals, this method was proven effective in measuring oxygen consumption in muscles. (16)

The aim of our study was to assess the value of near infrared spectroscopy (NIRS) in detecting skeletal muscle tissue oxygenation (StO2) in the critically ill.

\section{Materials and methods Patients}

The National Ethics Committee of Slovenia approved the study; informed consent was obtained from all patients or their relatives. The study was performed from November 2005 to May 2006. Patients admitted to ICU with localized infection, septic shock or cardiogenic shock, were included. The group of healthy volunteers was also included as controls.

\section{Definitions}

The criteria used for the diagnosis of localized infection and septic shockwere defined by the ACCP/SCCM consensus conference (1992). (17) Seriousness of disease was evaluated using SOFA (Sequential organ failure assessment score) (18), lactate (LacTest, Roch Diagnostics, Germany) and based upon the usage of vasopressors, inotropes and need for ventilatory support.

\section{Treatment}

All patients received standard treatment of localized infection, severe sepsis and septic or cardiogenic shock including: source control, IV fluids, catecholamine infusion, organ failure replacement and/ or support therapy, intensive control of blood glucose and corticosteroid substitution therapy according to current Surviving Sepsis Campaign Guidelines. (19) Mechanically ventilated patients were sedated with midazolam and/ or propofol infusion and no paralytic agents were used.

\section{Measurement of tissue oxygenation}

$\mathrm{StO}_{2}$ of thenar muscles was measured continuously with NIRS for 48 hours after admission. We used the tissue spectrometer Inspectra ${ }^{\text {TM }}$ (Hutchinson Technology Inc., BioMeasurement Division, Hutchinson, Min, USA). A 25 mm probe was placed on the skin of the thenar, where the highest $\mathrm{StO}_{2}$ value was shown. $\mathrm{StO}_{2}$ was recorded continuously for 3 minutes before, during and after arterial occlusion with an inflatable cuff. The cuff was inflated to $260 \mathrm{mmHg}$ for 90 seconds. In healthy volunteers and conscious patients measurements were conducted after 15 minutes of bed rest, avoiding any muscular contractions. Results were recorded in the form of a curve using InSpectra software and analyzed with InSpectra Analysis Program V2.0 (Hutchinson Technology Inc., USA) that works under MatLab 7.0 (MathWorks Inc., USA). Baseline $\mathrm{StO}_{2}$ (\%) was measured before inflating the cuff, hyperemic $\mathrm{StO}_{2}$ (\%) after deflation and curve change was calculated, downward $\mathrm{StO}_{2}$ slope (\%/min) during cuff inflation and upward $\mathrm{StO}_{2}$ slope 
(\%/min) after pressure was released. Muscular extraction rate (mOER, \%) in basal conditions was calculated as: mOER $=\left(1-\right.$ baseline $\mathrm{StO}_{2} /$ hyperemic $\left.\mathrm{StO}_{2}\right) * 100$.

The arterial occlusion test was performed in 5-minute intervals to study repeatability.

\section{Data analysis}

Data was expressed as absolute values or mean values \pm standard deviation (SD). One-way ANOVA with Tukey or Tamhane test for post hoc multiple comparisons and Chi-Square test was applied to analyze data (SPSS 12.0 for Windows ${ }^{\text {тм}}$, SPSS Inc., USA). A $p$ value of $<0.05$ was considered statistically significant. Repeatability bias of differences and $95 \%$ limits of agreement were calculated. (20) Bias was considered acceptable within $5 \%$ of mean value of paired measurements. In Bland-Altman graphs, $5 \%$ of values out of limits of agreement were considered clinically acceptable for repeatability to be valid.

\section{Results}

Data on patients and healthy volunteers are shown in table 1.

There was no difference in gender, age and length of treatment in ICU between groups $(p>0.05)$. Patients with cardiogenic and septic shock had a higher SOFA score $(p=0.001)$ and lower survival $(p=0.029)$ than patients with limited infection.

Table 2 shows that vital signs (blood pressure, heart rate, urine output, and hemoglobin saturation) did not differ significantly among patients with infections and those in shock ( $p>0.05)$

CRP- C-reactive protein, L- leucocytes, $\mathrm{Hb}$ - hemoglobin, arterial blood gas analysis: $\mathrm{pH}, \mathrm{pCO}_{2}, \mathrm{pO}_{2}, \mathrm{BE}, \mathrm{SaO}_{2}$.

C-reactive protein (CRP) was raised

Table 1. Demographics data on patients with cardiogenic shock, septic shock, limited infection and the control group of healthy volunteers.

\begin{tabular}{|c|c|c|c|c|c|c|c|}
\hline & $\begin{array}{l}\text { Cardiogenic } \\
\text { shock } \\
(n=17)\end{array}$ & $\begin{array}{l}\text { Septic } \\
\text { shock } \\
(n=14)\end{array}$ & $\begin{array}{l}\text { Limited } \\
\text { infection } \\
(n=14) \\
\end{array}$ & $\begin{array}{l}\text { Healthy } \\
\text { volunteers } \\
(n=15)\end{array}$ & $\begin{array}{l}\text { Total } \\
(\mathrm{n}=60)\end{array}$ & $\mathrm{F} / \mathrm{X}^{2}$ & $p$ \\
\hline $\begin{array}{l}\text { Gender (men/ } \\
\text { women) }\end{array}$ & $\begin{array}{l}7 / 10 \\
(41 \%)\end{array}$ & $\begin{array}{l}10 / 4 \\
(71 \%)\end{array}$ & $\begin{array}{l}8 / 6 \\
(57 \%)\end{array}$ & $\begin{array}{l}7 / 8 \\
(47 \%)\end{array}$ & $\begin{array}{l}32 / 28 \\
(53 \%)\end{array}$ & 3.201 & 0.362 \\
\hline Age (years) & $71 \pm 15$ & $64 \pm 15$ & $68 \pm 10$ & $42 \pm 18$ & $68 \pm 13$ & 0.843 & 0.438 \\
\hline SOFA (score) & $8 \pm 2$ & $9 \pm 4$ & $5 \pm 3$ & l & $8 \pm 3$ & 8.471 & 0.001 \\
\hline $\begin{array}{l}\text { Length of treatment } \\
\text { in ICU (days) }\end{array}$ & $14 \pm 9$ & $8 \pm 6$ & $9 \pm 8$ & l & $10 \pm 8$ & 2.115 & 0.135 \\
\hline $\begin{array}{l}\text { Survival (survived/ } \\
\text { died) }\end{array}$ & $\begin{array}{l}9 / 8 \\
(53 \%)\end{array}$ & $\begin{array}{l}7 / 7 \\
(50 \%)\end{array}$ & $\begin{array}{l}13 / 1 \\
(93 \%)\end{array}$ & / & $\begin{array}{l}28 / 17 \\
(62 \%)\end{array}$ & 7.068 & 0.029 \\
\hline
\end{tabular}

Table 2. Differences in vital signs among the three groups of patients (cardiogenic shock, septic shock and limited infection).

\begin{tabular}{|c|c|c|c|c|c|c|}
\hline & $\begin{array}{l}\text { Cardiogenic } \\
\text { shock } \\
(n=17)\end{array}$ & $\begin{array}{l}\text { Septic } \\
\text { shock } \\
(n=14)\end{array}$ & $\begin{array}{l}\text { Limited } \\
\text { infection } \\
(n=14)\end{array}$ & $\begin{array}{l}\text { Total } \\
(n=45)\end{array}$ & $F / X^{2}$ & $\mathrm{p}$ \\
\hline Body & & & & & & \\
\hline Temperature $\left({ }^{\circ} \mathrm{C}\right)$ & $37.3 \pm 0.9$ & $38.2 \pm 1.0$ & $37.1 \pm 1.2$ & $37.5 \pm 1.1$ & 2.895 & 0.073 \\
\hline $\begin{array}{l}\text { Systolic blood } \\
\text { pressure (mmHg) }\end{array}$ & $111 \pm 14$ & $123 \pm 31$ & $130 \pm 33$ & $120 \pm 26$ & 1.728 & 0.195 \\
\hline $\begin{array}{l}\text { Diastolic blood } \\
\text { pressure (mmHg) }\end{array}$ & $68 \pm 12$ & $69 \pm 13$ & $72 \pm 19$ & $70 \pm 15$ & 0.246 & 0.783 \\
\hline $\begin{array}{l}\text { Heart rate (beats/ } \\
\text { minute) }\end{array}$ & $107 \pm 25$ & $111 \pm 25$ & $91 \pm 16$ & $103 \pm 24$ & 2.008 & 0.153 \\
\hline $\begin{array}{l}\text { Urine output } \\
\text { (mL/hour) }\end{array}$ & $78 \pm 44$ & $36 \pm 44$ & $63 \pm 30$ & $60 \pm 38$ & 1.341 & 0.295 \\
\hline $\begin{array}{l}\text { Arterial } \\
\text { hemoglobin } \\
\text { saturation (\%) }\end{array}$ & $98 \pm 1$ & $98 \pm 1$ & $97 \pm 2$ & $98 \pm 1$ & 1.212 & 0.322 \\
\hline
\end{tabular}


in all groups (average CRP 195 $\mathrm{mg} / \mathrm{L})$. It was lowest in patients with cardiogenic shock (average CRP 123 $\mathrm{mg} / \mathrm{L}$ ) and highest in patients with septic shock (average CRP $261 \mathrm{mg} /$ $\mathrm{L})$, but differences were not statistically significant $(p=0.099)$. Patients with septic shock had higher values of leucocytes in comparison to patients with cardiogenic shock $(20 \pm 9$ * $10^{9}$ cells/L vs. $11 \pm 2 * 10^{9}$ Cell/L, p
$<0.05)$. Creatinine values were also higher in patients with cardiogenic and septic shock compared to patients with localized infection, although not statistically significant $(p=0.079)$ (table 3).

$\mathrm{FiO}^{2}$ - fraction of oxygen in inspired air.

Patients with septic shock required a higher percentage of inspired oxygen than patients with localized infection ( $p$
$<0.05)$. Most patients with cardiogenic (82\%) and septic shock (100 \%) were treated with vasoactive support. Most patients with cardiogenic shock also received inotropes (94\%) (table 4).

Values of baseline $\mathrm{StO}_{2}$ and followon $\mathrm{StO}_{2}$ were lower in patients with cardiogenic shock in comparison to patients with septic shock and patients with localized infection $(68.9 \pm 10.0$ $\%$ vs. $84.3 \pm 10.4 \%$ vs. $85.2 \pm 9.7$

Table 3. Differences in laboratory data among the three groups of patients (cardiogenic shock, septic shock and limited infection).

\begin{tabular}{|c|c|c|c|c|c|c|}
\hline & $\begin{array}{l}\text { Cardiogenic } \\
\text { shock } \\
(n=17)\end{array}$ & $\begin{array}{l}\text { Septic } \\
\text { shock } \\
(n=14)\end{array}$ & $\begin{array}{l}\text { Limited } \\
\text { infection } \\
(n=14) \\
\end{array}$ & $\begin{array}{l}\text { Total } \\
(n=45)\end{array}$ & $F / X^{2}$ & $\mathrm{p}$ \\
\hline CRP (mg/L) & $123 \pm 53$ & $243 \pm 154$ & $142 \pm 108$ & $186 \pm 135$ & 2.524 & 0.099 \\
\hline L $\left({ }^{*} 10^{9}\right.$ cell & & & & & & \\
\hline count/L) & $11 \pm 2$ & $20 \pm 9$ & $17 \pm 9$ & $17 \pm 8$ & 1.540 & 0.246 \\
\hline $\mathrm{Hb}(\mathrm{g} / \mathrm{L})$ & $115 \pm 15$ & $125 \pm 20$ & $123 \pm 13$ & $123 \pm 16$ & 0.532 & 0.597 \\
\hline $\begin{array}{l}\text { Creatinine } \\
(\mu \mathrm{mol} / \mathrm{L})\end{array}$ & $199 \pm 165$ & $227 \pm 186$ & $74 \pm 27$ & $156 \pm 148$ & 2.933 & 0.079 \\
\hline $\mathrm{pH}$ & $7.36 \pm 0.09$ & $7.29 \pm 0.19$ & $7.38 \pm 0.83$ & $7.34 \pm 1.36$ & 1.261 & 0.306 \\
\hline $\mathrm{pCO}_{2}(\mathrm{kPa})$ & $5.7 \pm 1.4$ & $6.4 \pm 1.6$ & $6.0 \pm 1.2$ & $6.1 \pm 1.3$ & 0.265 & 0.770 \\
\hline $\mathrm{pO}_{2}(\mathrm{kPa})$ & $11.6 \pm 2.4$ & $20.3 \pm 6.6$ & $17.3 \pm 10.0$ & $17.3 \pm 8.3$ & 1.524 & 0.242 \\
\hline $\mathrm{BE}(\mathrm{mmol} / \mathrm{L})$ & $-4.4 \pm 6.1$ & $-3.5 \pm 9.9$ & $1.4 \pm 5.1$ & $-0.7 \pm 7.5$ & 1.301 & 0.297 \\
\hline $\mathrm{SaO}_{2}(\%)$ & $97 \pm 3$ & $98 \pm 3$ & $97 \pm 4$ & $98 \pm 3$ & 0.732 & 0.494 \\
\hline $\begin{array}{l}\text { Lactate } \\
(\mathrm{mmol} / \mathrm{L})\end{array}$ & $4.3 \pm 3.2$ & $3.5 \pm 2.6$ & $1.0 \pm 0.5$ & $3.4 \pm 2.8$ & 2.516 & 0.100 \\
\hline
\end{tabular}

Table 4. Supportive treatment given to patients with cardiogenic shock, septic shock and limited infection.

\begin{tabular}{|c|c|c|c|c|c|c|}
\hline & $\begin{array}{l}\text { Cardiogenic } \\
\text { shock } \\
(n=17)\end{array}$ & $\begin{array}{l}\text { Septic } \\
\text { shock } \\
(n=14)\end{array}$ & $\begin{array}{l}\text { Limited } \\
\text { infection } \\
(n=14)\end{array}$ & $\begin{array}{l}\text { Total } \\
(\mathrm{n}=45)\end{array}$ & $F / X^{2}$ & $\mathrm{p}$ \\
\hline $\mathrm{FiO}_{2}(\%)$ & $50 \pm 18$ & $75 \pm 20$ & $46 \pm 12$ & $57 \pm 22$ & 7.639 & 0.003 \\
\hline $\begin{array}{l}\text { Artificial ventilation } \\
\text { (yes/no) }\end{array}$ & $\begin{array}{l}16 / 1 \\
(94 \%)\end{array}$ & $\begin{array}{l}12 / 2 \\
(86 \%)\end{array}$ & $\begin{array}{l}9 / 5 \\
(64 \%)\end{array}$ & $\begin{array}{l}37 / 8 \\
(82 \%)\end{array}$ & 1.857 & 0.395 \\
\hline $\begin{array}{l}\text { Patients with } \\
\text { vasoactive support } \\
\text { (noradrenalin, } \\
\text { dopamine) } \\
\text { (yes/no) }\end{array}$ & $\begin{array}{l}14 / 3 \\
(82 \%)\end{array}$ & $\begin{array}{l}14 / 0 \\
(100 \%)\end{array}$ & $\begin{array}{l}5 / 9 \\
(36 \%)\end{array}$ & $\begin{array}{l}33 / 12 \\
(73 \%)\end{array}$ & 13.319 & 0.001 \\
\hline $\begin{array}{l}\text { Patients with } \\
\text { inotropes } \\
\text { (dobutamine, } \\
\text { levosimendan) } \\
\text { (yes/no) }\end{array}$ & $\begin{array}{l}16 / 1 \\
(94 \%)\end{array}$ & $\begin{array}{l}7 / 7 \\
(50 \%)\end{array}$ & $\begin{array}{l}3 / 11 \\
(21 \%)\end{array}$ & $\begin{array}{l}27 / 19 \\
(60 \%)\end{array}$ & 13.648 & 0.001 \\
\hline
\end{tabular}


$\%, \mathrm{p}<0.05)$. mOER was higher in healthy volunteers and patients with cardiogenic shock compared to patients with localized infection (11.9 $\pm 3.8 \%$ vs. $14.8 \pm 7.3 \%$ vs. $7.6 \pm$ $5.4 \%, p<0.05)$. The downward $\mathrm{StO}_{2}$ slope was steeper in patients with cardiogenic shock compared to septic shock $(-17.2 \pm 6.3 \%$ vs. $-9.1 \pm 2.6 \%$, $\mathrm{p}<0.05$ ) (table 5).

NIRS repeatability analysis was done in 55 measurements on 45 patients (table 6). Figures 1 to 4 represent bias of repeated measurements with $95 \%$ limits of agreement. Biases of baseline $\mathrm{StO}_{2}$ and hyperemic $\mathrm{StO}_{2}$ are acceptable, while biases of downward $\mathrm{StO}_{2}$ slope and upward $\mathrm{StO}_{2}$ are beyond the $5 \%$ of acceptable limits. $95 \%$ of values are within limits of agreement for baseline $\mathrm{StO}_{2}$, hyperemic $\mathrm{StO}_{2}$ and downward $\mathrm{StO}_{2}$ slope. One measurement is out of agreed limits for all four variables and eliminating it from analysis improves the result for the downward $\mathrm{StO}_{2}$ slope and upward $\mathrm{StO}_{2}$ slope so they also meet the criteria of repeatability.

\section{Discussion}

The current study confirmed repeatability of skeletal muscle tissue oxygenation measurements with NIRS in critically ill patients with cardiogenic shock, septic shock and localized infection. We found lower values of baseline $\mathrm{StO}_{2}$, hyperemic $\mathrm{StO}_{2}$, higher mOER and a steeper downward $\mathrm{StO}_{2}$ slope in patients with cardiogenic shock in comparison to patients with septic shock.

\section{Repeatability}

Purpose of repeatability evaluation is to prove NIRS is clinically applicable.
As can be seen in figures 1 to 4 , measurements of baseline $\mathrm{StO}_{2}$ and hyperemic $\mathrm{StO}_{2}$ are within acceptable criteria according to Bland and Altman. One measurement has been out of agreed limits in all four variables and eliminating it from analysis had improved the result for the downward $\mathrm{StO}_{2}$ slope and upward $\mathrm{StO}_{2}$ slope so they also met the criteria of repeatability.

We have found NIRS method to be precise and repeatable, but since we have not compared NIRS results with more standardized methods of measurement, we cannot claim that measured results aretruevalues of tissue oxygenation. To avoid measurement error, a correct measurement procedure is important. A probe with the appropriate intraoptode distance should be used and the same position on the muscle should be used for probe

Table 5. Near infrared spectroscopy (NIRS) measurements in patients with cardiogenic shock, septic shock, limited infection, and in healthy volunteers.

\begin{tabular}{lcccccc}
\hline & $\begin{array}{l}\text { Cardiogenic } \\
\text { shock } \\
(\mathrm{n}=17)\end{array}$ & $\begin{array}{l}\text { Septic } \\
\text { shock } \\
(\mathrm{n}=14)\end{array}$ & $\begin{array}{l}\text { Limited } \\
\text { infection } \\
(\mathrm{n}=14)\end{array}$ & $\begin{array}{l}\text { Healthy } \\
\text { volunteers } \\
(\mathrm{n}=15)\end{array}$ & $\mathrm{F} / \mathrm{X}^{2}$ & $\mathrm{p}$ \\
\hline $\begin{array}{l}\text { Baseline } \mathrm{StO}_{2} \\
(\%)\end{array}$ & $68.9 \pm 10.0$ & $84.3 \pm 10.4$ & $85.2 \pm 9.7$ & $84.1 \pm 3.8$ & 12,530 & $<0.001$ \\
$\mathrm{Hyperemic}$ & $80.8 \pm 7.8$ & $91.8 \pm 8.3$ & $92.2 \pm 8.3$ & $95.5 \pm 1.7$ & 13.102 & $<0.001$ \\
$\begin{array}{l}\mathrm{StO} \text { (\%) } \\
\mathrm{mOER}\end{array}$ & $14.8 \pm 7.3$ & $8.1 \pm 7.8$ & $7.6 \pm 5.4$ & $11.9 \pm 3.8$ & 4.518 & 0.007 \\
$\begin{array}{l}\text { Downward } \\
\mathrm{StO} \\
\text { (\%/min) }\end{array}$ & $-17.2 \pm 6.3$ & $-9.1 \pm 2.6$ & $-13.3 \pm 4.5$ & $-37.0 \pm 7.6$ & 70.156 & $<0.001$ \\
$\begin{array}{l}\text { Upward } \mathrm{StO} \\
\text { slope }(\% / m i n)\end{array}$ & $75.4 \pm 31.7$ & $59.1 \pm 35.9$ & $73.9 \pm 61.9$ & $284.8 \pm 107.0$ & 39.399 & $<0.001$ \\
\hline
\end{tabular}

Table 6. Repeatability of 55 near infrared spectroscopy (NIRS) measurements in patients with infection, shock and in healthy volunteers.

\begin{tabular}{lllll}
\hline & $\begin{array}{l}\text { Bias of } \\
\text { differences }\end{array}$ & $\begin{array}{l}\text { 95\% Limits of } \\
\text { agreement }\end{array}$ & $\begin{array}{l}\text { Mean of paired } \\
\text { measurements }\end{array}$ & $\begin{array}{l}\text { Number of outliers } \\
(\%)\end{array}$ \\
\hline $\begin{array}{l}\text { Baseline } \mathrm{StO}_{2}(\%) \\
\text { Hyperemic } \mathrm{StO}_{2}(\%)\end{array}$ & $0.74 \pm 0.41$ & \pm 5.96 & $82.30 \pm 1.46$ & $2(3.6 \%)$ \\
$\begin{array}{l}\text { Downward } \mathrm{StO}_{2} \\
\text { slope }(\% / \mathrm{min})\end{array}$ & $-0.40 \pm 0.56$ & \pm 8.06 & $88.88 \pm 1.18$ & $2(3.6 \%)$ \\
$\begin{array}{l}\text { Upward } \mathrm{StO}_{2} \text { slope } \\
(\% / \mathrm{min})\end{array}$ & $-0.80 \pm 1.90$ & \pm 9.52 & $-12.03 \pm 0.79$ & $1(1.8 \%)$ \\
\hline
\end{tabular}


placement. The optimal position on the muscle is where $\mathrm{StO}_{2}$ is highest (largest volume of transilluminated tissue) to avoid underestimation of $\mathrm{StO}_{2}$. It is also important to avoid muscle activity during measurements since contractions change results considerably.

Skeletal muscle tissue oxygenation in cardiogenic and septic shock

Tissue oxygenation in vivo depends on concentration of hemoglobin, number of open capillaries and vessel circumference (vasodilatation or vasoconstriction). (1)

Peripheral tissue increases oxygen extraction (mOER) in cardiogenic shock where tissue flow is decreased.

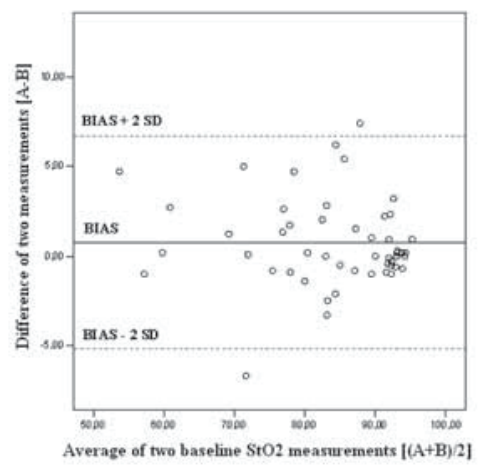

A - first measurement,

$\mathrm{B}$ - repeated measurement.

Figure 1. Bland Altman graph of muscle oxygen saturation for baseline $\mathrm{StO}_{2}$.

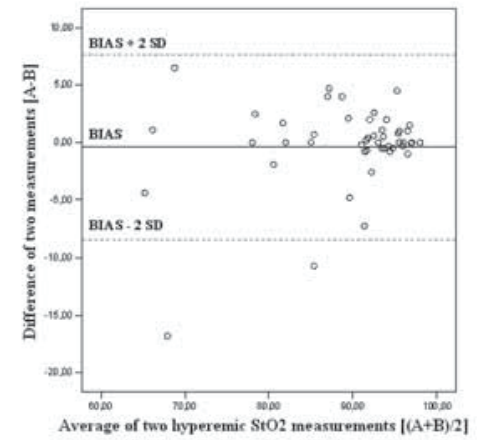

A - first measurement,

$\mathrm{B}$ - repeated measurement.

Figure 2. Bland Altman graph of muscle oxygen saturation for hyperemic $\mathrm{StO}_{2}$.
(21) Lower tissue blood flow was found in patients who later died than in patients who survived. (22) We had similar findings in our study, with a few exceptions, that could be explained by an unusually strong inflammatory response reducing tissue extraction via the same mechanism as in sepsis.

In septic shock mOER is reduced because of changes in microcirculation and mitochondria while tissue blood flow is increased with some areas hyperperfusedand somehypoperfused. Tissue oxygenation is thus near normal or even increased. These findings have been confirmed in numerous studies on animals $(23,24)$ and humans. (25)

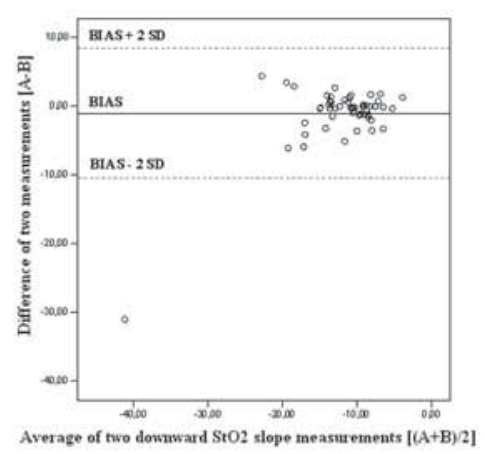

A - first measurement, B - repeated measurement.

Figure 3. Bland Altman graph of muscle oxygen saturation for downward $\mathrm{StO}_{2}$ slope.

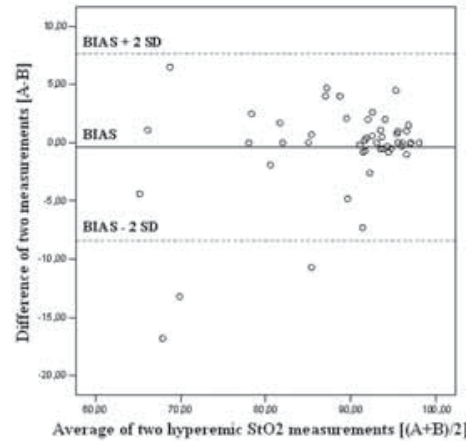

A - first measurement,

$B$ - repeated measurement.

Figure 4. Bland Altman graph of muscle oxygen saturation for upward $\mathrm{StO}_{2}$ slope.
Other studies found that in severe inflammation, lasting over 12-16 hours, cellular breathing and ATP production is slowed down. (26) Current opinion is that multi-organ failure is an attempt to preserve affected cells switching to a hibernation-like state. (27)

Muscular oxygen extraction rate for patients with localized infection is similar to that in patients with septic shock. This unexpected result could be attributed to baseline $\mathrm{StO}_{2}$ higher than $90 \%$ in 8 out of 14 patients. This shows a weakness in our definition of mOER, as higher baseline $\mathrm{StO}_{2}$ affects calculations. Our definition of $\mathrm{mOER}$, as a relationship between baseline $\mathrm{StO}_{2}$ and hyperemic $\mathrm{StO}_{2}$, is only a robust estimate of $\mathrm{VO}_{2}$ versus $\mathrm{DO}_{2}$ ratio. Further studies are needed to confirm our results using additional methods for local tissue metabolism assessment.

Analyzing the $\mathrm{StO}_{2}$ curve change (downward $\mathrm{StO}_{2}$ slope) can give us a good estimation of $\mathrm{VO}_{2}$. The baseline curve (before cuff inflation) represents the difference between oxygen delivery and consumption and is constant for the respective tissue. After cuff inflation, when oxygen delivery is shut down, the $\mathrm{StO}_{2}$ curve slopes down because of continued oxygen consumption. The linear drop, as shown in figure 1, is true for shorter total arterial constrictions, while the drop for longer cuff inflation is exponential and reaches a plateau after 3 minutes, when consumption is also shut down. The slope of the curve in lower values of $\mathrm{StO}_{2}$ (majority of hemoglobin is desaturated) is probably also affected by myoglobin. Myoglobin and hemoglobin absorptions cannot be differentiated with NIRS. In higher values of $\mathrm{pO}_{2}$, myoglobin is saturated and constant and does not affect relative $\mathrm{StO}_{2}$ measurements. The role of myoglobin in lower $\mathrm{pO}_{2}$ and $\mathrm{StO}_{2}$ values is unknown. $(28,29)$ It is therefore reasonable to measure the $\mathrm{StO}_{2}$ slope right after cuff inflation when $\mathrm{VO}_{2}$ is not slowed down because of ischemia and myoglobin does not affect the measurements.

After cuff deflation a short period of hyperemia prevails with vasodilatation 
and vessel recruitment. It is not known which mechanism is predominant.

\section{Conclusions}

Repeatability of tissue oxygenation measurements using the NIRS method was confirmed. We found lower values of baseline $\mathrm{StO}_{2}$, hyperemic $\mathrm{StO}_{2}$, higher mOER and a steeper downward $\mathrm{StO}_{2}$ slope in patients with cardiogenic shock in comparison to patients with septic shock. This confirms that oxygen extraction is intact and even increased in patients with cardiogenic shock.

\section{Key messages}

- NIRS measurements are repeatable.

- Muscular oxygen extraction is intact and even increased in patients with cardiogenic shock.

- Muscular oxygen extraction is decreased in patients with septic shock.

\section{REFERENCES}

1. Hameed SM, Aird WC, Cohn SM. Oxygen delivery. Crit Care Med 2003;31(12 Suppl):S658-67.

2. Lim N, Dubois MJ, De Backer D, Vincent JL. Do all nonsurvivors of cardiogenic shock die with low cardiac index. Chest 2003;124:1885-91.

3. Ince C, Sinaasappel M. Microcirculatory oxygenation and shunting in sepsis and shock. Crit Care Med 1999;27:1369-77.

4. Fink MP. Cytopathic hypoxia: Is oxygen use impaired in sepsis as a result of an acquired intrinsic derangement in cellular respiration? Critical Care Clin 2002;18:165-75.

5. Creteur J, De Backer D, Vincent JL. A dobutamine test can disclose hepatospalnchnic hypoperfusion in septic patients. Am J Resp Crit Care Med 2002;160:839-45.

6. Lima A, Bakker J. Noninvasive monitoring of peripheral perfusion. Intensive Care Med 2005;31:1316-26.

7. Abou-Khalil B, Scalea TM, Trooskin SZ, Henry SM, Hitchcock R. Hemodynamic responses to shock in young trauma patients: need for invasive monitoring. Crit Care Med 1994;22:633-9.

8. Scalea TM, Maltz S, Yelon J, Trooskin SZ, Duncan AO, Sclafani SJ. Resuscitation of multiple trauma and head injury: role of crystalloid fluids and inotropes. Crit Care Med 1994;22:1610-5.

9. Ivatury RR, Simon RJ, Islam S, Fueg A, Rohman M, Stahl WM. A prospective randomized study of end points of resuscitation after major trauma: global oxygen transport indices versus organ-specific gastric mucosal pH. J Am Coll Surg 1996;183:145-54.

10. Sessler DI. Skin-temperature gradients are a validated measure of fingertip perfusion. Eur J Appl Physiol 2003;89:401-2.

11. Boushel R, Piantadosi CA. Near-infrared spectroscopy for monitoring muscle oxygenation. Acta Physiol Scand 2000;168:615-22.

12. Wahr JA, Tremper KK, Samra S, Delpy DT. Near-infrared spectroscopy: theory and applications. J Cardiothorac Vasc Anesth 1996;10:406-18.

13. Shepherd JT. Circulation to skeletal muscle. In: Abboud FM, Shepherd JT, editors. Handbook of physiology. Vol. 3. Bethesda (USA); 1983. p. 319-70.

14. Malmstrom BG, Aasa R. The nature of the CuA center in cytochrome c oxidase. FEBS Lett 1993;325:49-52.

15. De Blasi R, Quaglia E, Gasparetto A, Ferrari M.Muscle oxygenation by fast near infrared spectrophotometry (NIRS) in ischemic foreram. Adv Exp Med Biol 1992;316:163-72.

16. Colier WN, Meeuwsen IB, Degens H, Oeseburg B. Determination of oxygen consumption in muscle during exercise using near infrared spectroscopy. Acta Anaesthesiol Scand 1995;39(Suppl 107):151-55.

17. Bone RC, Balk RA, Cerra FB, Dellinger RP, Fein AM, Knaus WA, et al. Definitions for sepsis and organ failure and guidelines for the use of inovative therapies in sepsis. Chest 1992;101:1644-55.

18. Sair M, Etherington PJ, Winlove P, Ewans TW. Tissue oxygenation and perfusion in patients with systemic sepsis. Crit Care Med 2001;29:1343-49.

19. Dellinger RP, Carlet JM, Masur H, Gerlach H, Calandra T, Cohen J, et al. Surviving Sepsis Campaign guidelines for management of severe sepsis and septic shock. Intensive Care Med 2004;30:536-55.

20. Bland JM, Altman DG. Statistical methods for assessing agreement between two methods of clinical measurements. Lancet 1986:307-10.

21. Shoemaker WC. Circulatory mechanisms of shock and their mediators. Crit Care Med 1987;15:787-94.

22. De Backer D, Creteur J, Dubois MJ, Sakr Y, Vincent JL. Microvascular alterations in patients with acute severe heart failure and cardiogenic shock. Am Heart J 2004;147:91-9.

23. Simonson SG, Welty-Wolf K, Huang YT, Griebel JA, Caplan MS, Fracica PJ, et al. Altered mitochondrial redox responses in gram negative septic shock in primates. Circ Shock 1994;43:34-43.

24. Duhaylongsod FG, Griebel JA, Bacon DS, Wolfe WG, Piantadosi CA. Effects of muscle contraction on cytochorme a, a3 redox state. J Appl Physiol 1993;75:790-7.

25. Girardis M, Rinaldi L, Busani S, Flore I, Mauro S, Pasetto A. Muscle perfusion and oxygen consumption by near-infrared spectroscopy in septic shock and non-septic patients. Intensive Care Med 2003;29:1173-6.

26. Singer M, Brealey D. Mitochondrial dysfunction in sepsis. Biochem Soc Symp 1999;66:149-66. 
27. Singer M, DeSantis V, Vitale D, Jeffcoate W. Multiorgane failure is an adaptive, endocrine-mediated, metabolic response to overwhelming systemic inflammation. Lancet 2004;364:545-7.

28. Tran TK, Sailasuta N, Kreutzer U, Hurd R, Chung Y, Mole P, et al. Comparateive analysis of NMR and NIRS measurements of intracellular $\mathrm{PO}_{2}$ in human skeletal muscle. Am J Physiol 1999;276:R1682-90.

29. Mancini DM, Wilson JR, Bolinger L, Li H, Kendrick K, Chance B, et al. In vivo magnetic resonance spectroscopy measurement of deoxymyglobin during exercise in patients with heart failure. Demonstration of abnormal muscle metabolism despite adequate osygenation. Circulation 1994;90(1):500-8.

\section{ACKNOWLEDGMENT}

The study was supported by a grant from the Slovenian Agency for Research and Development. 